\title{
ENVIRONMENTAL CARE ATTITUDE OF THE STUDENTS IN SENIOR HIGH SCHOOL AT PATI REGENCY
}

\author{
Novika Adi Wibowo ${ }^{1}$, Sarwono ${ }^{2}$, Yasin Yusup ${ }^{3}$ \\ ${ }^{1,2,3}$ Geography Education, Universitas Sebelas Maret \\ E-mail: novikadiw14@gmail.com
}

\begin{abstract}
The research aims to determine the environmental care attitude in Senior High School 1 Kayen. The research samples were the tenth-grade students, eleventh-grade students, and third-grade students of Social Science (IPS) class at Senior High School 1 Kayen. The research used Slovin formula to obtain 192 samples from the tenth grade, eleventh grade, and twelfth grade. The study used a random sampling technique. Questionnaires were used as the data collection techniques to measure knowledge about environmental care attitudes using calculation techniques of Likert scale and percentage formula. The result shows the students in Senior High have the moderate category on environmental care attitude, with a total frequency of 89 students consisting of tenth-grade students, eleventh-grade students, and twelfth-grade students in Social Science (IPS) class with a percentage score of 46,35\%. In an attempt to increase students' environmental care, we suggest several educational agents, such as Educational supervisors, Principals, and Teachers give the students examples of good actions to the environment in daily routine.
\end{abstract}

Keywords: Environmental; Care Attitude Environment; Education

\section{A. INTRODUCTION}

Humans and their environment are inextricably intertwined. The rapid pace of technology has affected the environment negatively and positively as well. On the one hand, the advancing technology, if used irresponsibly, can lead environmental degradation. On the other, it can be used to help us keep the environment clean which can benefit our health. The living environment is a space occupied by a living being along with living and invisible living things in plants, animals, humans and microorganisms occupying a certain space
(Akib, 2014). The environment is a combination of all the things around us that affect our life. The temperature of hot and humid air makes us stifling, on the other hand, the temperature of the air is very cold makes us shiver. Not only temperature, other air quality, for example the content of gases and particles also affect our lives. The air that smells foul and dusty disturbs the comfort of our life. So air is one of the environmental elements for us. Water is also a component of our environment because the quality and quantity of water 
affects our lives. Clean water can be a healthy drink, on the other hand, dirty water can cause disease (Wiryono, 2013).

Human attitudes and behaviour determine the good and bad condition of an environment. The surrounding environment in the form of living things such as animals and plants or the form of inanimate objects must be maintained. If the surrounding environment is not maintained, then it is likely to harm humans. On the other side, if maintained, the environment can provide humans welfare (Suprayogo,

2013).

Table 1. Polution Index Calculation Result at Sani River Water

\begin{tabular}{cccc}
\hline No & Monitoring Location & Pollution Index Value & Water Quality Status \\
\hline 1 & Upstream & 2,28 & Slightly Polutted \\
\hline 2 & The Middle & 2,27 & Slightly Polluted \\
\hline 3 & Downstream & 5,86 & Moderate Polluted \\
\hline
\end{tabular}

Source: (Rina Mailisa et al., 2020)

Based on the results of the Pollution Index (PI) value, it could be concluded that the Sani river water quality status from upstream to downstream has decreased from slightly to moderate polluted conditions. The quality of Sani river water did not meet the designation quality standards for water class II so that the Sani river water should not be applied as a means of water recreation, freshwater aquaculture, animal husbandry, and agriculture irrigation water (Rina Mailisa et al., 2020).

Lack of knowledge about the environment often results in the exploitation and destruction of natural resources resulting in loss of biodiversity
(R \& J., 2012). Many people believe that environmental education is one of the most important factors for preventing problems (Özden, 2008). High school need to improve and implement a best strategy to accommodate student's skill in solving environmental problem(Keselman et al., 2011). Education is one aspect that can affect the world of the future and is the most effective way in shaping a society. The students as a part of school community also have a great contribution in the changing of society perspective in environmental issue (Idris et al., 2012). Students who develop their thinking skills have a chance to approach everyday problems including 
environmental issues using those competences (Yazar Soyad1, 2015). One of the character learning programs that must be given to students is the character of environmental care. Character education of environmental care is expected to be able to instil a caring attitude towards the environment to the students (Kresnawati, 2013). Environmental care is an attitude that prevents damage to the surrounding natural environment and develops efforts to restore the natural damage that has occurred (Narwanti, 2011). The environmental care attitude of students can arise when students are invited to learn to care by taking care (Saptono, 2011). This caring attitude is expected to be able to change students' attitudes to be well-informed about the environment. Environmental education can be taught at a school that needs to be taught earlier.

Building character is not an instant job and is done simultaneously, yet it requires a long and synergised process. However, it is ironic that character education is merely in the realm of knowledge. Therefore, due to that consternation, an idea arises to apply the process of character education at school/campus. The reality spread in our society, especially in educational institutions, indicates that the concept of character or morals is still restricted to knowledge. Characters are taught by definitions, terms, concepts, and the others that are related to knowledge, and yet it lacks the actualization. The school, including teachers and principal, teaches the students about character values, such as honesty, caring, help, democracy, discipline, etc., but the teacher and principal are not able to be the role model of the value itself (Takdir, 2014).

Environmental education is initiated within the families from the individual births and continues at the primary education level and higher education level (Ors, 2012). Environmental education is an effort to provide environmental knowledge among the students. It assumes that the increase in environmental knowledge leads to an increase in care attitude as well as the decrease in future environmental damage.

The Intergovernmental Panel on Climate Change (IPCC) in 2007 in the BPS Environmental Care Indicator, in addition to natural factors, human activity is also the main cause of the increase in the concentration of greenhouse gases (GHG) in the earth's atmosphere, which ultimately contributes to the increase in the 
concentration of greenhouse gases (GHG) in the earth's atmosphere. contribute to global warming, climate change and environmental damage (Badan Pusat Statistik, 2012). Based on the results of a study by the Central Statistics Agency on 33 provinces in Indonesia in 2012, it shows that the environmental care behavior of the community is still low with a score of 0.57 from a range of $1-10$. This is indicated by several human activities in the form of the use of transportation, energy, forest burning and livestock which are actually carried out to meet the needs of life. The relationship between human activities and environmental problems is actually not as simple as whether an activity is allowed to be carried out, but it is hoped that everyone can be responsible for the damage to the environment it causes.

In order to solve any issues in environment, it needs high quality human resource that having thinking ability and skills related to environment (Rafiei \& Davari, 2015). The way to overcome this problem is by instilling environmental care for children from early childhood. The environmental care attitude can be interpreted as efforts to preserve, prevent, and improve the natural environment. Human attitudes can be changed or educated through education. The environmental care attitude is one out of 18 attitudes that must be developed in character education. A caring attitude is also reflected in the standards of completeness domains that must be met by students in the 2013 curriculum.

The development of awareness of the conditions existing in the environment can be achieved through education in schools. Schools carry out a proactive role in helping families and communities by developing a caring and respectful environment where students learn core and ethical values (Pala, 2011). Schools should play their role in forming an awareness of the environment (Mustakin, 2011). The character building towards the environment shall be built within the students. The purpose of character education is to encourage the birth of good children. Growing up with good character, children will grow up with the capacity and commitment to do their best (Handayani \& Indartono, 2016). This character can be started from trivial issues, such as the provision of adequate trash cans and the formulation of action plans about environmental awareness programs. Through the formation of this character, it is expected that a generation 
that has environmental concerns is expected to emerge.

There is an effort to form the character of environmental care attitude. The book of Teaching Environmental Ethics states that "ethical issues about the environment are generally raised in the context of environmental crises that are understood as environmental crises produced by misguided values. These erroneous values emphasise consumerism and consumption and understand the environment as a resource that seems very bound" (Palmer et al., 2014). Learning that highlights the context of environmental crisis provides inappropriate meaning for students in which they assume that preserving the environment needs to be done by minimising the consumption of natural resources. Through the educational sector, one can change the perspective and increase the capacity of ecological insight that can drive environmental behaviour and friendly lifestyle (Ahmad, 2010).

The research aims to determine the environmental care attitude in Senior High School 1 Kayen. The research samples were the tenth-grade students, eleventh-grade students, and third-grade students of Social Science (IPS) class at Senior High School 1 Kayen. The results obtained will be a reference from the teacher and related parties.

\section{B. MATERIALS AND METHODS}

This research was conducted at Senior High School 1 Kayen located on Jl.Kayen-Sukolilo, Kayen Sub-District, Pati District, Central Java. Research Location Map can be seen in Figure 2. 


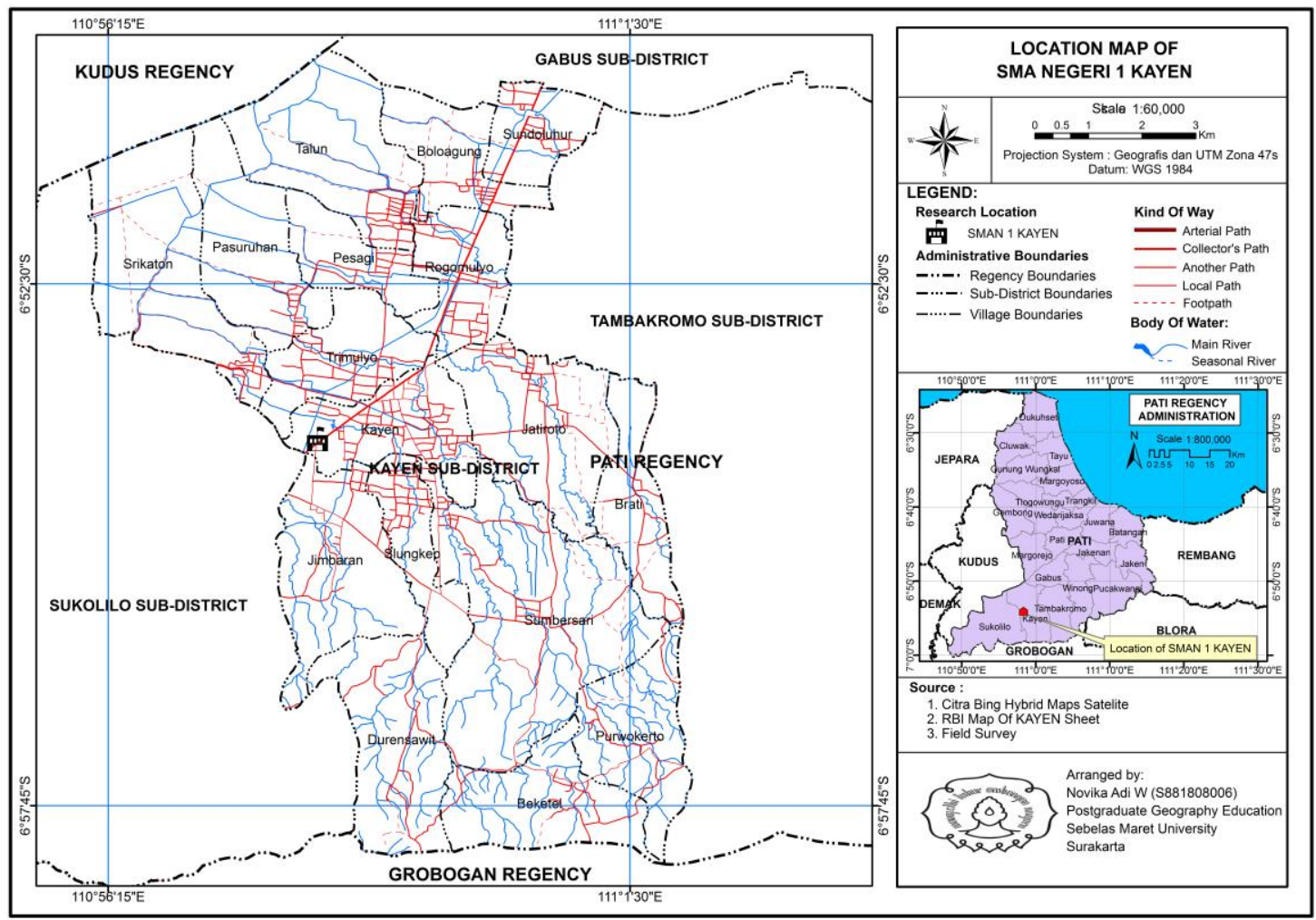

Figure 1. Map Of Research Location Source : Primary Data

The method used in this research was quantitative descriptive method. The aim of the research was to find out the environmental care attitude of the students. The idea behind the present study is the students' insufficient awareness to keep their surroundings clean. They made school environment untidy with rubbish. Also, there was no any effort to make their classrooms tidy again. The tenth-grade students, eleventhgrade students, and twelfth-grade students of Social Sciences (IPS) class at Senior High School Kayen 1 were selected as research samples. The following is the number of students sample:
- Tenth-grade students of Social Science class : 175 students

- Eleventh-grade students of Social Science class $\quad: 175$ students

- Twelfth-grade students of Social Sciences class $\quad: 175$ students

In determining the total number of sample, the present study uses Slovin's formulation (Sugiyono, 2013). It can be seen as follows:

$$
\mathrm{n}=\frac{N}{1+N e^{2}}
$$

Where:

- $\mathrm{n}$ : Total sample

- $\mathrm{N}$ : Total population

- e : Error tolerance 
In the application, the first thing I would do was to determine error of tolerance. The error of tolerance is represented by percentage where the higher percentage, the more accurate the error of tolerance. For instance, if error of tolerance was $5 \%$, it means it has $95 \%$ accuracy level. This research has $10 \%$ accuracy level. Based on the formulation, I was able to determine the number of sample. It is shown in the following:

- Tenth-grade students of Social Science class : 64 students

- Eleventh-grade students of Social Science class : 64 students

- Twelfth-grade students of Social Sciences class : 64 students

In determining the number of samples, the research used Slovin formula to obtain a sample totaling 64 tenth-grade students, 64 eleventh-grade students, and 64 twelfth-grade students of Social Science class. The research used a random sampling technique. Data collection technique used in this research was questionnaires while measuring knowledge about environmental care attitudes used in this research was calculation techniques with Likert scale and percentage formula. Finding out the environmental care attitude of the students in Senior High School Kayen 1 can be done through the questionnaire. The questionnaire used in this research was a structured questionnaire which provides several statements related to the number of alternatives used as possible answers that can be chosen by respondents. In terms of the large-scale trial, the questionnaire was used to determine the environmental care attitude of the students in learning activities. In this research, researchers used several written statements given to students. Conducting an assessment of environmental care attitude is based on the Likert scale assessment system through five available answer choices namely strongly agree (SS), agree (S), doubtful (R), disagree (TS) and strongly disagree (STS). The questionnaire was used to reveal the environmental care attitude of the students and was constructed in the form of statements of students' environmental care attitude towards their school environment. Each respondent was allowed to choose one choice out of five alternative answers provided for each statement. Respondents were asked to give a tick $(\sqrt{ })$ to the provided answer by selecting one of the five options. The following table is a Likert scale and scores for environmental care attitude scores: 
Table 2. Likert Scale and Knowledge Score for Environmental Care Attitudes

\begin{tabular}{ccc}
\hline No & Categories & Score \\
\hline 1 & Strongly Agree & 5 \\
\hline 2 & Agree & 4 \\
\hline 3 & Doubtful & 3 \\
\hline 4 & Disagree & 2 \\
\hline 5 & Strongly Disagree & 1 \\
\hline
\end{tabular}

Source : (Sugiyono, 2013)

In analyzing students attitude The percentage formula: towards environmental care, I using a $\quad \mathrm{NP}=\frac{n}{s m} \times 100 \%$

range of scores, then analyzed using the Where:

percentage formula.

Range of scores:

Score Range $=\frac{\text { the highest score-lowest value }}{\text { the number of values }}$

(Husein, 2011)
- NP : Percentage Value

- $\mathrm{n} \quad$ : Observation result

- $\mathrm{s}$ m : Maximum score

(Sudijono, 2012)

Table 3. Percentage Category Value

\begin{tabular}{ccc}
\hline Score & Percentage & Description \\
\hline $100,9-120$ & $85,00 \%-100 \%$ & Ver High \\
\hline $81,7-100,8$ & $69,00 \%-84,00 \%$ & High \\
\hline $62,5-81,6$ & $53,00 \%-68,00 \%$ & Moderate \\
\hline $43,3-62,4$ & $37,00 \%-52,00 \%$ & Low \\
\hline $24-43,2$ & $20,00 \%-36,00 \%$ & Very Low
\end{tabular}

Source : Primary Data

\section{RESULTS AND DISCUSSION}

This research was conducted at Senior High School 1 Kayen located on Jl.Kayen-Sukolilo, Kayen Sub-District, Pati District, Central Java. It is astronomically situated between $6^{\circ} 54^{\prime}$ 09” SL dan $110^{\circ} 58^{\prime} 32^{\prime \prime} \mathrm{EL}$. In this research design, there are 4 indicators that were used to measure environmental care, namely: energy saving behavior, disposing of waste, utilizing water, contributing to carbon emissions, and healthy living habits (Kementerian Lingkungan Hidup, 2013). 
Table 4. Environmental Care Attitude of Senior High School 1 Kayen

\begin{tabular}{|c|c|c|c|c|c|c|c|c|c|c|c|c|c|}
\hline \multirow[t]{2}{*}{ No } & \multirow[t]{2}{*}{ Class } & \multicolumn{2}{|c|}{ Very Low } & \multicolumn{2}{|c|}{ Low } & \multicolumn{2}{|c|}{ Moderate } & \multicolumn{2}{|c|}{ High } & \multicolumn{2}{|c|}{$\begin{array}{l}\text { Very } \\
\text { High }\end{array}$} & \multirow[t]{2}{*}{$\begin{array}{c}\text { Number } \\
\text { of } \\
\text { Frequency }\end{array}$} & \multirow[t]{2}{*}{$\begin{array}{c}\text { Number of } \\
\text { Percentages } \\
(\%)\end{array}$} \\
\hline & & $\mathrm{F}$ & $(\%)$ & $\mathrm{F}$ & $(\%)$ & $\mathrm{F}$ & $\%$ & $\mathrm{~F}$ & $\%$ & $\mathrm{~F}$ & $(\%)$ & & \\
\hline 1 & $\begin{array}{l}\text { X IPS } \\
\text { (Tenth } \\
\text { Grade) }\end{array}$ & 6 & $3,12 \%$ & 15 & $7,81 \%$ & 30 & $15,62 \%$ & 13 & $6,77 \%$ & 0 & $0 \%$ & 64 & $33,33 \%$ \\
\hline 2 & $\begin{array}{c}\text { XI IPS } \\
\text { (Eleventh } \\
\text { Grade) }\end{array}$ & 5 & $2,60 \%$ & 16 & $8,33 \%$ & 28 & $14,58 \%$ & 15 & $7,81 \%$ & 0 & $0 \%$ & 64 & $33,33 \%$ \\
\hline 3 & $\begin{array}{c}\text { XII IPS } \\
\text { (Twelfth } \\
\text { Grade) }\end{array}$ & 3 & $1,56 \%$ & 22 & $11,45 \%$ & 31 & $16,14 \%$ & 8 & $4,16 \%$ & 0 & $0 \%$ & 64 & $33,33 \%$ \\
\hline & Total & 14 & 7,29 & 53 & $27,60 \%$ & 89 & $46,35 \%$ & 36 & $18,75 \%$ & 0 & $0 \%$ & 192 & $100 \%$ \\
\hline
\end{tabular}

After the data were obtained based on the questionnaire given to the respondent, the first step to do was finding out the percentage number in the form of a table using the percentage formula. The results of the obtained score analysis indicate that there were 6 tenth-grade students of social science (IPS) class whose scores were in the range of 24-43,2 classified into very low category, 15 tenth-grade students of social science (IPS) class whose scores were in the range of 43,3-62,4 classified into the low category, 30 tenth-grade students of social science (IPS) class whose scores were in the range of 62,581,6 classified into the moderate category and 13 tenth-grade students of social science (IPS) class whose scores were in the range of 81,7-100,8 classified into the high category.
The scores obtained by 5 eleventhgrade students of social science (IPS) class were in the range of 24-43,2 classified into very low category, 16 eleventh-grade students of social science (IPS) class whose scores were in the range of 43,3-62,4 classified into the low category, 28 eleventh-grade students of social science (IPS) class whose scores were in the range of $62,5-81,6$ classified into the moderate category, and 15 eleventh-grade students of social science (IPS) class whose scores were in the range of $81,7-100,8$ classified into the high category.

Then, the score obtained by 3 twelfth-grade students of social science (IPS) class was in the range of 24-43,2 classified into the very low category, 22 twelfth-grade students of social science (IPS) class whose scores were in the 
range of 43,3-62,4 classified into the low category, 31 twelfth-grade students of social science (IPS) class whose scores were in the range of $62,5-81,6$ classified into the moderate category, and 8 twelfth-grade students of social science (IPS) class whose scores were in the range of $81,7-100,8$ classified into the high category.

Table 4 shows that the questionnaires given to the entire research sample, which was to the tenth grade of social science (IPS) class, show a percentage of $3,12 \%$ classified into very low category with the total frequency of 6 students, the low category shows a percentage of $7,81 \%$ with the total frequency of 15 students, the moderate category shows a percentage of $15,62 \%$ with the total frequency of 30 students, the high category shows a percentage of $6,77 \%$ with the total frequency of 13 students. Meanwhile, there was no student in the very high category so that the percentage shown was $0 \%$.

The students in the eleventh grade of social science (IPS) class showed a percentage of $2,60 \%$ classified into the very low category with the total frequency of 5 students, the low category showed a percentage of $8,33 \%$ with the total frequency of 16 students, the moderate category showed a percentage of $14,58 \%$ with the total frequency of 28 students, and the high category showed a percentage of $7,81 \%$ with the total frequency of 15 students. Meanwhile, there was no student in the very high category so that the percentage shown was $0 \%$.

The students of twelfth grade in social science (IPS) class showed a percentage of $1,56 \%$ classified into the very low category with the total frequency of 3 students, the low category showed a percentage of $11,45 \%$ with the total frequency of 22 students, the moderate category showed a percentage of $16,14 \%$ with the total frequency of 31 students, and the high category showed a percentage of $4,16 \%$ with the total frequency of 8 students. Meanwhile, there was no student in the very high category so that the percentage shown was $0 \%$.

Thus, that it can be concluded that the students of Senior High School 1 Kayen have environmental care attitude within the moderate category with a total frequency of 89 students containing the tenth-grade students of social science (IPS) class, eleventh-grade students of social science (IPS) class and twelfthgrade students of social science (IPS) class in which the percentage score was 
$46,35 \%$. The strategy of forming totalling environmental care character can be done by making the integration with students' daily activities (Mushlich, 2011). The implementation of this strategy can be done by supervisors, principals, administrative staff and teachers in schools through being the role models for students. Moreover, the spontaneous activities can be carried out by the teacher to their students in the school, for example, reprimanding students who commit bad behaviour and remind them to be good or have good behaviour, carrying out cleaning activities in the classroom to familiarise students always to keep their environment clean and comfortable. Instilling Early environmental education is surely aimed at the preservation and sustainability of the environment itself by which people the people can maintain and preserve the environment. Therefore, environmental education is expected to be able to increase the students' awareness as the next generation of this nation in efforts to preserve the environment for future sustainability. Explained that environmental knowledge is someone's basic knowledge about something that can be done to protect the environment (Lee et al., 2011).

\section{CONCLUSIONS}

Based on the results of data analysis and discussion, it can be concluded that: The analysis of environmental care attitude obtained through questionnaires for tenth-grade students, eleventh-grade students, and twelfth-grade students social science (IPS) class at Senior High School 1 Kayen showed that environmental care was in the moderate category with a total frequency of 89 students consisting of tenth-grade students, eleventh-grade students, and twelfth-grade students of social science (IPS) class with percentage score of $46,35 \%$. In an attempt to increase students' environmental care, we suggest several educational agents, such as educational supervisors, principals, and teachers give the students examples of good actions to the environment in daily routine. The renewal of this research with previous research, namely in this study can be used to determine the environmental care attitude of students, and these results can be used as a reference for teachers and related parties to improve environmental care as an effort to educate students to care about the environment. 


\section{E. REFERENCES}

Ahmad, M. (2010). Pendidikan Lingkungan Hidup dan Masa Depan Ekologi Manusia. Jurnal Forum Tarbiyah, 8, 57-71.

Akib, M. (2014). Hukum Lingkungan Perspektif Global dan Nasional. PT. Raja Grafindo Persada.

Badan Pusat Statistik. (2012). Indikator Perilaku Peduli Lingkungan Hidup.

Handayani, N., \& Indartono, S. (2016). The Implementation Of Multicultural Character Education. International Conference on Ethics of Business, Economics, and Social Science, 508-518.

Husein, U. (2011). Metode Penelitian Untuk Skripsi dan Tesis Bisnis (11th ed.). PT Raja Grafindo Persada.

Idris, F., Hassan, Z., Ya'acob, A., Gill, S. K., \& Awal, N. A. M. (2012). The Role of Education in Shaping Youth's National Identity. Procedia - Social and Behavioral Sciences, 59, 443-450. https://doi.org/https://doi.org/10.1 016/j.sbspro.2012.09.299

Kementerian Lingkungan Hidup. (2013). Perilaku Masyarakat Peduli Lingkungan (Survei KLH 2012).

Keselman, A., Levin, D. M., Kramer, J. F., Matzkin, K., \& Dutcher, G. (2011). Educating Young People about Environmental Health for Informed Social Action. Umwelt Und Gesundheit Online, 4(December 2010), 1-8. http://www.ncbi.nlm.nih.gov/pub med/24383062\%0Ahttp://www.pu bmedcentral.nih.gov/articlerender. fcgi? artid=PMC3875179

Kresnawati, N. (2013). Korelasi Kualitas Pembelajaran Geografi dan Hasil Belajar Terhadap Sikap Pedui Lingkungan Siswa Kelas XII IPS
SMA N 1 Ponorogo. Jurnal Pendidikan Humaniora, 10(3), 290-303.

Lee, J. T., Glantz, S. A., \& Millett, C. (2011). Effect of smoke-free legislation on adult smoking behaviour in England in the 18 months following implementation. PloS One, 6(6), e20933. https://doi.org/10.1371/journal.po ne.0020933

Mushlich, M. (2011). Pendidikan Karakter menjawab Tantangan Krisis Multidimensional. Bumi Aksara.

Mustakin, B. (2011). Pendidikan Karakter: Membangun Delapan Karakter Emas Menuju Indonesia Bermartabat. Samudra Biru.

Narwanti, S. (2011). Pendidikan Karakter Pengintegrasian 18 Nilai Peembentuk Karakter dalam Mata Pelajaran. Familia.

Ors, F. (2012). Environmental education and the role of media in environmental education in Turkey. Procedia - Social and Behavioral Sciences, 46, 13391342. https://doi.org/doi: 10.1016/j.sbspro.2012.05.298

Özden, M. (2008). Environmental Awareness and Attitudes of Student Teachers: An Empirical Research. International Research in Geographical and Environmental Education, 17(1), 40-55.

https://doi.org/10.2167/irgee227.0

Pala, A. (2011). The Need For Character Education Turkey. International Journal Of Social Sciences And Humanity Studies, 3, 23-32.

Palmer, C., McShane, K., \& Sandler, R. (2014). Environmental ethics. Annual Review of Environment and Resources, 39, 419-442. https://doi.org/10.1146/annurev- 
environ-121112-094434

R, L. S., \& J., Q. D. (2012). Where would Darwin have been without taxonomy? Journal of Biological Education, 43, 51-52.

Rafiei, N., \& Davari, F. (2015). The Role of Human Resources Management on Enhancing the Teaching Skills of Faculty Members. Materia Socio-Medica, 27(1), 35-38. https://doi.org/10.5455/msm.2014. 27.35-38

Rina Mailisa, E., Yulianto, B., \& Warsito, B. (2020). Water quality condition of Sani river as source of drinking water of PDAM Tirta Bening in Pati Regency. E3S Web Conf., 202, 06040. https://doi.org/10.1051/e3sconf/20 2020206040

Saptono. (2011). Dimensi-dimensi Pendidikan Karakter. Erlangga.
Sudijono, A. (2012). Pengantar Evaluasi Pendidikan. PT Raja Grafindo Persada.

Sugiyono. (2013). Metode Penelitian Pendidikan (Pendekatan Kuantitatif, Kualitatif, dan $R$ \& $D)$. Alfabeta.

Suprayogo, I. (2013). Pengembangan Pendidikan Karakter. UINMALIKI PRESS.

Takdir, M. (2014). Pendidikan yang Mencerahkan. UMM Press.

Wiryono. (2013). Pengantar Ilmu Lingkungan. Pertelon Media.

Yazar Soyadı, B. B. (2015). Creative and Critical Thinking Skills in Problem-based Learning Environments. Journal of Gifted Education and Creativity, 2(2), 71-71.

https://doi.org/10.18200/jgedc.201 5214253 